\title{
Plant Antibacterial Peptides and their Possible Oligomerization
}

\author{
Dutta Chowdhury S. ${ }^{1,2}$, Glyakina A.V. ${ }^{1,3}$, Lahiri A. ${ }^{2}$, Galzitskaya O.V. ${ }^{1}$ \\ ${ }^{1}$ Institute of Protein Research, RAS, Pushchino, Moscow Region, Russia \\ ${ }^{2}$ University of Calcutta, Kolkata, West Bengal, India \\ ${ }^{3}$ IMPB RAS - Branch of KIAM RAS, Pushchino, Moscow Region, Russia \\ ogalzit@vega.protres.ru
}

\begin{abstract}
Plant antimicrobial peptides form an integral component of the innate immunity of plants and have activities against a broad spectrum of microorganisms. They were classified into various families and most share general features such as the presence of structure-stabilizing disulfide bridges and positive charge. Self-aggregation was suggested as one of the possible mechanisms for the effect of these antimicrobial peptides. Here, we have created a dataset comprising plant peptides with activity against gram positive and gram negative bacteria. We have found that the majority of the antibacterial peptides in this dataset contain at least one amyloidogenic region. We proposed that these amyloidogenic regions could help in the self-aggregation of the peptides and presented a possible ringlike oligomeric structure of the plant antimicrobial peptide $\mathrm{NaD} 1$.

Key words: Plant antimicrobial peptide, Oligomerization, Antibacterial peptide, Multiple Sequence Alignment.
\end{abstract}

\section{Растительные антибактериальные пептиды и их возможная олигомеризация}

\author{
Дутта Чоудари С. ${ }^{1,2}$, Глякина А.В. ${ }^{1,3}$, Лахири А. ${ }^{2}$, Галзитская О.В. ${ }^{1}$ \\ ${ }^{1}$ Институт белка РАН, Пущино, Россия \\ ${ }^{2}$ Университет Калькутты, Калькутта, Западная Бенгалия, Индия \\ ИМПБ РАН - филиал ИПМ им. М.В. Келдьима РАН \\ ogalzit@vega.protres.ru
}

\begin{abstract}
Растительные антимикробные пептиды являются неотъемлемой частью наследственного иммунитета растений и обладают активностью против широкого спектра микроорганизмов. Эти пептиды были расклассифицированы на различные семейства, и большинство из них имеют общие характеристики, такие как наличие стабилизирующих структуру дисульфидных мостиков и положительный заряд. Предполагается, что самоагрегация является одним из возможных механизмов воздействия этих противомикробных пептидов. В настоящей работе была создана база данных, включающая в себя растительные пептиды с активностью против грамположительных и грамотрицательных бактерий. На основании этой базы данных было обнаружено, что в большинстве антибактериальных пептидов содержится, по меньшей мере, один амилоидогенный участок. Мы предположили, что наличие амилоидогенных участков может помочь в самоагрегации этих пептидов и представили возможную кольцеобразную олигомерную структуру растительного антимикробного пептида $\mathrm{NaD} 1$.
\end{abstract}

Ключевые слова: растительный антимикробный пептид, олигомеризация, антибактериальный пептид, множественное пространственное выравнивание.

\section{Introduction}

Plants are constantly exposed to various environmental and/or pathogenic stresses, such as fungi, bacteria, insects, drought etc. To counter these potentially lethal conditions, plants have evolved sophisticated defence mechanisms ranging from cell wall, which forms a physical barrier, to constitutive or inducible expression of chemical compounds including the production of antimicrobial peptides (AMPs). The AMPs are an important component of the innate immunity in fungi, insects, animals and plants [1-5]. AMP expression in plant cells can be either constitutive 
Table 1. Number of predicted amyloidogenic regions

\begin{tabular}{|c|c|c|c|c|c|}
\hline & $\begin{array}{c}\text { Number of } \\
\text { peptides with 1 } \\
\text { region }\end{array}$ & $\begin{array}{c}\text { Number of } \\
\text { peptides with 2 } \\
\text { regions }\end{array}$ & $\begin{array}{c}\text { Number of peptides } \\
\text { with 3 regions }\end{array}$ & $\begin{array}{c}\text { Number of } \\
\text { peptides with 4 } \\
\text { regions }\end{array}$ & $\begin{array}{c}\text { Number of } \\
\text { peptides with no } \\
\text { region }\end{array}$ \\
\hline FoldAmyloid & 60 & 18 & 1 & 0 & 31 \\
\hline PASTA 2.0 & 17 & 3 & 0 & 0 & 90 \\
\hline WALTZ & 13 & 1 & 0 & 0 & 96 \\
\hline AGGRESCAN & 36 & 28 & 8 & 1 & 37 \\
\hline
\end{tabular}

(e.g. in specialized tissues or organs) or can be induced (e.g. pathogen challenge) [6-8]. Plant AMPs are cysteine-rich cationic peptides which act against a broad range of organisms [7, 9]. Based on sequence similarity, number of cysteine residues, disulfide bond patterns and tertiary structure, plant AMPs have been divided into several distinct subgroups like thionins, defensins, cyclotides, hevein-like peptides, knottin-type peptides, lipid transfer proteins, $\alpha$-hairpinin, and snakins [7, 9, 10]. These peptides have been isolated from various plant organs such as seeds, roots, flowers, stems and leaves. As potential candidates for increasing pathogen resistance to engineered crops and leads for newgeneration drugs, AMPs generated a lot of interest in recent years [11-17].

Several studies also focused towards the elucidation of their antimicrobial properties and mechanism of action [9, 18]. One common theme observed for the action of most of these antibacterial peptides is selfaggregation upon reaching a threshold concentration [9]. Here, in this study we have collected plant AMPs with antibacterial activity from the Antimicrobial Peptide Database (APD3) [19] and predicted amino acid regions within these antibacterial peptides which could help in their self-aggregation and oligomerization. To find these amino acid regions we have utilized four popular web servers which predict the amyloidogenic regions within a given peptide sequence. Finally, we also tried to suggest an oligomeric form of a plant defensin called NaD1 which is present in tobacco [20].

\section{Materials and methods}

\subsection{Construction of the dataset}

We have created a dataset containing 110 antimicrobial peptides from plants. To construct this dataset, we have used the Antimicrobial Peptide database (APD3) [19] where search terms "plants" in combination with "gram positive/negative bacteria" were used to extract antimicrobial peptides. Further, we used an in-house python script to store the data into a tabular and more manageable form with APD ids, sequences and additional information of the corresponding peptides.

\subsection{Prediction of amyloidogenic regions}

In this study we have used four web servers, namely FoldAmyloid [21], PASTA 2.0 [22], WALTZ [23] and AGGRESCAN [24], to predict the amyloidogenic regions of the antibacterial peptides extracted as mentioned earlier. We further analysed the number of regions predicted by each of these four methods.

\subsection{Antibacterial peptide length distribution and amino acid composition}

We have calculated the amino acid composition and the distribution of peptide lengths from our dataset using an in-house python script. The plots were created using the R statistical software package [25].

\subsection{Multiple sequence alignment}

We have isolated three groups of antibacterial peptides from our dataset belonging to the plant 'defensin', 'thionin' and 'cyclotide' families. Sequences from each group were then used to obtain multiple sequence alignment using Clustal Omega [26] and weblogos were generated using WebLogo 3 tool $[27,28]$.

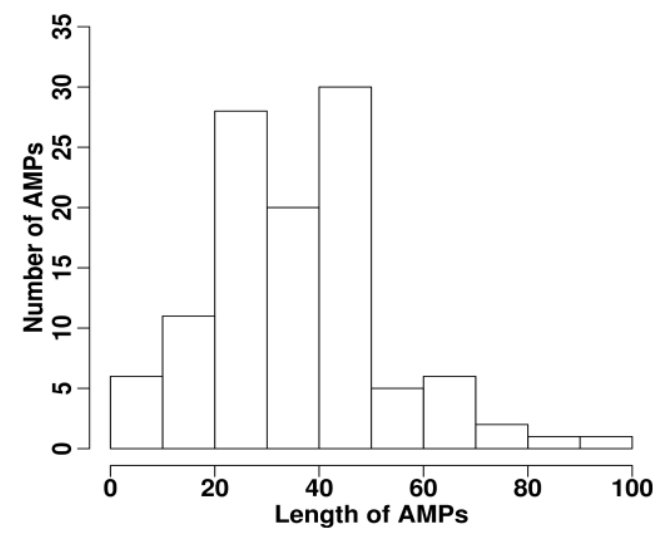

Fig. 1. Length distribution of plant antibacterial peptides.

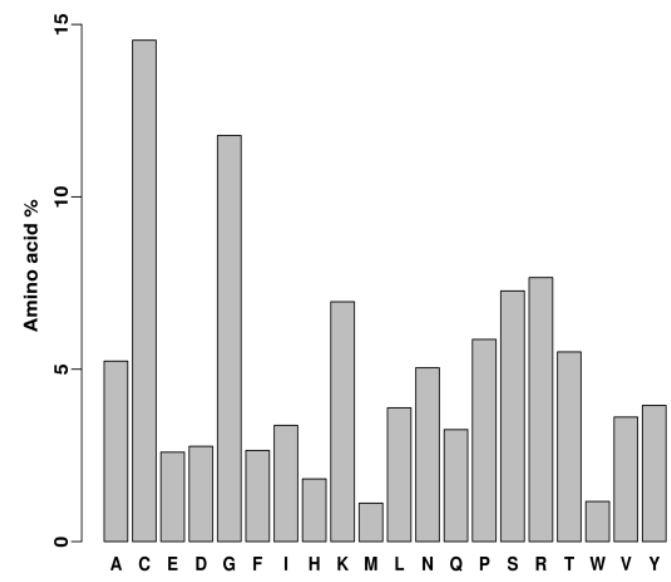

Fig. 2. Amino acid compositions of plant antibacterial peptides. 
(a)

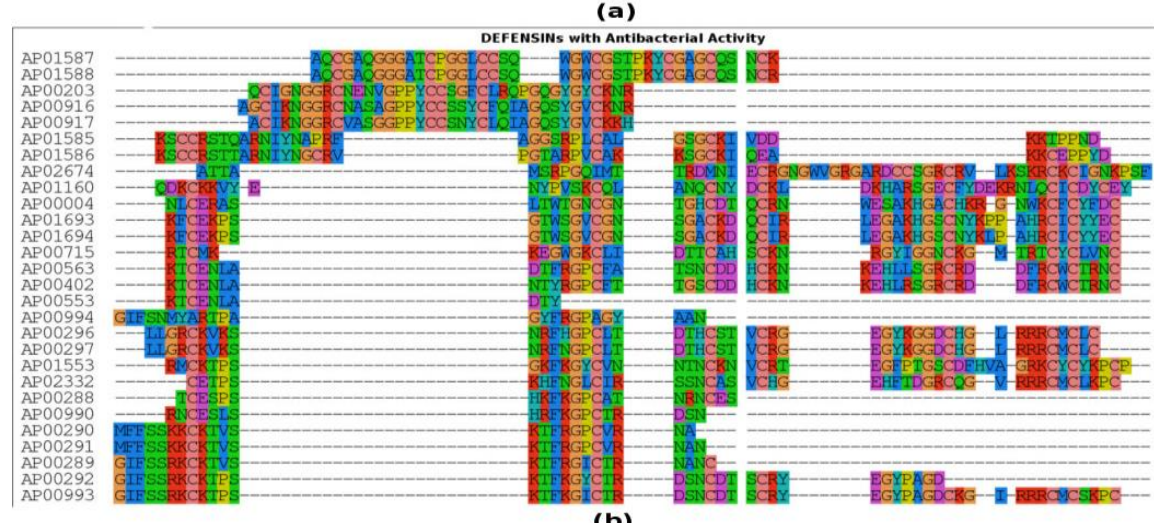

(b)

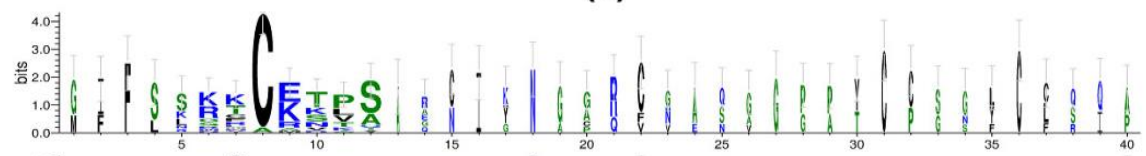

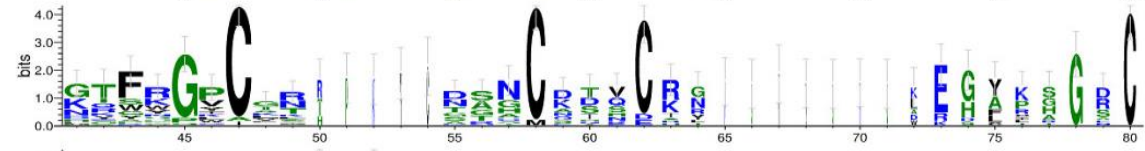
$\underset{85}{2.0000}$

Fig. 3. Multiple sequence alignment of antibacterial defensins and their corresponding (a).Weblogo (b).

(a)

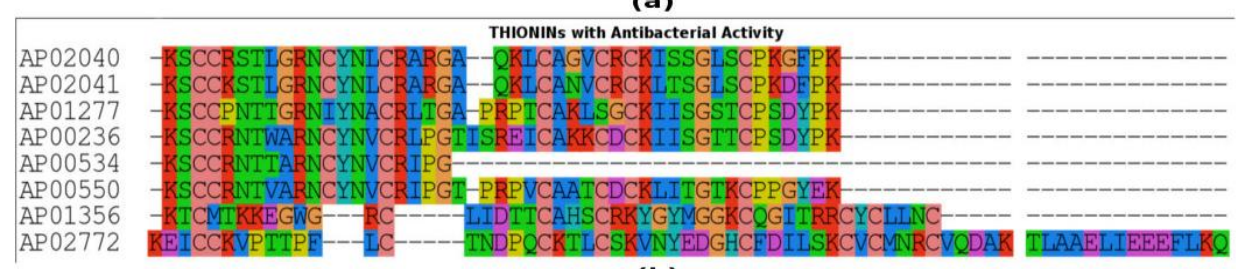

(b)

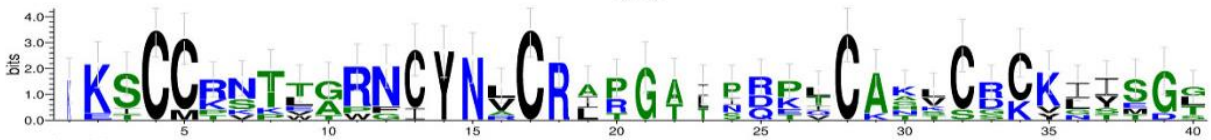

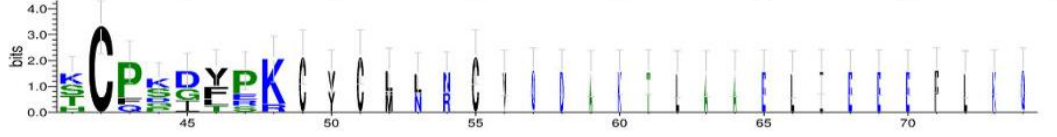

Fig. 4. Multiple sequence alignment of antibacterial thionins and their corresponding (a). Weblogo (b).

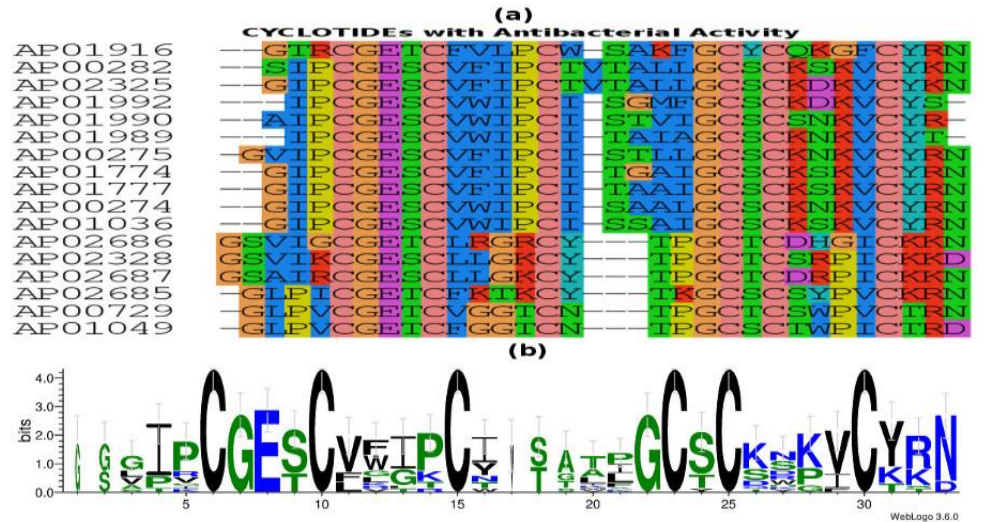

Fig. 5. Multiple sequence alignment of antibacterial cyclotides and their corresponding (a). Weblogo (b). 


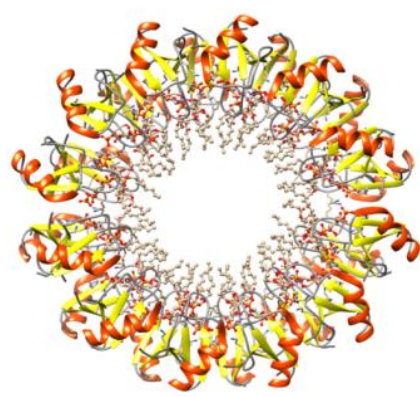

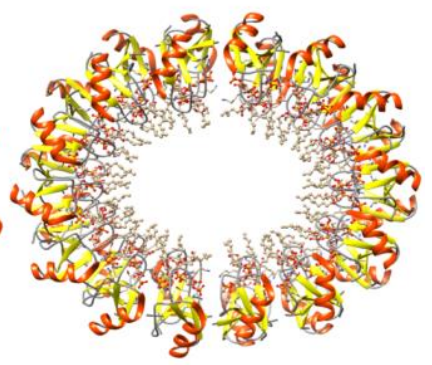

Fig. 6. Proposed oligomeric forms of plant defensin $\mathrm{NaD} 1$ containing (a) $24 \mathrm{NaD} 1-\mathrm{PIP}_{2}$ units and (b) $28 \mathrm{NaD}_{-}-\mathrm{PIP} \mathrm{P}_{2}$ units. Diameter of the inner hole is about $30 \AA$, and the outer one is about $100 \AA$.

\subsection{Construction of oligomer structure}

Structure 4CQK (14-mers) [20] from the Protein Data Bank was taken as template to construct a ring-like oligomer structure for plant defensin NaD1. Packing of oligomers was done by the YASARA program [29].

\section{Results and discussions}

\subsection{Predicted amyloidogenic regions}

We have analysed the number of peptides with different number of predicted amyloidogenic regions and found that this greatly varies with the choice of web servers (Table 1). We noticed that FoldAmyloid and AGGRESCAN reported the maximum number of peptides with at least one amyloidogenic regions. In our dataset there are only 16 antibacterial peptides for which all of the algorithms used in this study predicted absence of any amyloidogenic region.

\subsection{Length distribution of plant antibacterial peptides and amino acid composition}

In our dataset the length of the plant antibacterial peptides varies from 7-92 amino acid residues with majority of the peptides having a length of 20-50 amino acid residues (Fig. 1). When we analysed the amino acid composition (Fig. 2) of all the peptides in our dataset, we found that cysteine was the most frequently occurring amino acid, which was expected because of the prevalence of highly conserved cysteine disulfide bridges. We also noticed that glycine was the second most frequent amino acid residue followed by the positively charged arginine and lysine and polar serine residues.

\subsection{Multiple sequence alignment}

Multiple sequence alignments and weblogo (Figures 3-5) analysis have clearly showed very distinct features among the three groups we studied, namely defensins, thionins and cyclotides. In general, cysteine residues were highly conserved in all the three families. In the case of defensin, we observed the presence of 5 short and disjoint motifs (Fig. 3,b) whereas no such motifs were present in the thionin (Fig. 4,b) and the cyclotide (Fig. 5,b) families. We also observed that defensin and thionin families have more conserved positively charged residues such as lysine and arginine compared to cyclotides.

\subsection{Oligomerization of AMPs}

For the function of some AMPs, formation of oligomeric structure is necessary. Different authors have suggested several mechanisms for permeabilization of membranes $[9,30]$. In recent years some of the oligomeric structures of plant AMPs bound to their membrane target have been reported and their structures were deposited in the Protein Data Bank [20, 31-33]. We found that most of the peptides in our dataset were predicted to have at least one amyloidogenic region which strengthens our belief that these regions could help the AMPs to form oligomers. From protein data bank we extracted a 14-mer crystal structure of plant defensin NaD1 [20] and proposed a ring-like oligomer structure (Figure 6) containing either 24 or $28 \mathrm{NaD} 1$ monomers bound to phosphatidylinositol 4.5-bisphosphate $\left(\mathrm{PIP}_{2}\right)$. We proposed that this ring-like oligomeric unit could be the building block of the observed $\mathrm{NaD} 1$ fibrils [20]. It should be mentioned that $\mathrm{PIP}_{2}$ is important for oligomerization, and the diameter of the fibrils is about100 $\AA$ [20], which coincides (or match) with the outer diameter of the oligomers (Fig. 6).

\section{Conclusion}

Based on the idea that self-aggregation of peptides might be a common theme for the mode of action of plant antibacterial peptides [9], we used four [21-24] popular prediction tools for finding amyloidogenic regions in our antibacterial dataset. We found that only 16 peptides, out of the 110 peptides in our dataset, were predicted to not have any amyloidogenic region. Three families, namely defensins, thionins and cyclotides have highly conserved cysteine residues. We have proposed a possible ring-like oligomeric structure for plant defensin NaD1 which might explain the formation of NaD1 fibrils [20]. 


\section{Acknowledgments}

S.D.C. acknowledges the support from the International Centre for Genetic Engineering and Biotechnology (ICGEB) for the SMART Fellowship. The studies were partially supported by the Russian Science Foundation (18-14-00321) for A.V.G. and O.V.G.

\section{References}

1. Wong J.H., Xia L., Ng T.B. A review of defensins of diverse origins. Curr. Protein Pept. Sci. 2007. V. 8. P. 446-459.

2. Hancock R.E.W., Lehrer R. Cationic peptides: a new source of antibiotics. Trends Biotechnol. 1998. V. 16. P. 82-88.

3. Dathe M., Wieprecht T. Structural features of helical antimicrobial peptides: their potential to modulate activity on model membranes and biological cells. Biochim. Biophys. Acta. 1999. V. 1462. P. 71-87.

4. Aerts A.M., François I.E.J.A., Cammue B.P.A., Thevissen K. The mode of antifungal action of plant, insect and human defensins. Cell. Mol. Life Sci. 2008. V. 65. P. 2069-2079.

5. Zasloff M. Antimicrobial peptides of multicellular organisms. Nature. 2002. V. 415. P. 389-395.

6. Bowles D. Defense-Related Proteins In Higher Plants. Annu. Rev. Biochem. 1990. V. 59. P. 873907.

7. Broekaert W.F., Cammue B.P.A., De Bolle M.F.C., Thevissen K., De Samblanx G.W., Osborn R.W., et al. Antimicrobial Peptides from Plants. CRC Crit. Rev. Plant. Sci. 1997. V. 16. P. 297-323.

8. Heil M., Bostock R.M. Induced systemic resistance (ISR) against pathogens in the context of induced plant defences. Ann. Bot. 2002. V. 89. P. 503-512.

9. Barbosa Pelegrini P., Del Sarto R.P., Silva O.N., Franco O.L., Grossi-de-Sa M.F. Antibacterial peptides from plants: what they are and how they probably work. Biochem. Res. Int. 2011. V. 2011. doi: 10.1155/2011/250349.

10. Tam J.P., Wang S., Wong K.H., Tan W.L. Antimicrobial Peptides from Plants. Pharmaceutical. 2015. V. 8. P. 711-757.

11. Benko-Iseppon A.M., Galdino S.L., Calsa T.Jr, Kido E.A., Tossi A., Belarmino L.C., et al. Overview on Plant Antimicrobial Peptides. Curr. Protein Pept. Sci. 2010. V. 11. P. 181-188.

12. Kido E.A., Pandolfi V., Houllou-Kido L.M., Andrade P.P., Marcelino F.C., Nepomuceno A.L., et al. Plant Antimicrobial Peptides: An Overview of SuperSAGE Transcriptional Profile and a Functional Review. Curr. Protein Pept. Sci. 2010. V. 11. P. 220-230.

13. Padovan L., Scocchi M., Tossi A. Structural aspects of plant antimicrobial peptides. Curr. Protein Pept. Sci. 2010. V.11. P. 210-219.
14. Da Rocha Pitta M.G., da Rocha Pitta M.G., Galdino S.L. Development of novel therapeutic drugs in humans from plant antimicrobial peptides. Curr. Protein Pept. Sci. 2010. V. 11. P. 236-247.

15. Ajesh K., Sreejith K. Peptide antibiotics: an alternative and effective antimicrobial strategy to circumvent fungal infections. Peptides. 2009. V. 30. P. 999-1006.

16. Farrokhi N., Whitelegge J.P., Brusslan J.A. Plant peptides and peptidomics. Plant Biotechnol. J. 2008. V. 6. P. 105-134.

17. Sels J., Mathys J., De Coninck B.M.A., Cammue B.P.A., De Bolle M.F.C. Plant pathogenesis-related (PR) proteins: a focus on PR peptides. Plant. Physiol. Biochem. 2008. V. 46. P. 941-950.

18. Cools T.L., Struyfs C., Cammue B.P., Thevissen K. Antifungal plant defensins: increased insight in their mode of action as a basis for their use to combat fungal infections. Future Microbiol. 2017. V. 12. P. 441-454.

19. Wang G., Li X., Wang Z. APD3: the antimicrobial peptide database as a tool for research and education. Nucleic Acids Res. 2016. V. 44. P. D1087-1093.

20. Poon I.K., Baxter A.A., Lay F.T., Mills G.D., Adda C.G., Payne J.A., et al. Phosphoinositidemediated oligomerization of a defensin induces cell lysis. Elife. 2014. V. 3. P. e01808.

21. Garbuzynskiy S.O., Lobanov M.Y., Galzitskaya O.V. FoldAmyloid: a method of prediction of amyloidogenic regions from protein sequence. Bioinformatics. 2010. V. 26. P. 326332.

22. Walsh I., Seno F., Tosatto S.C.E., Trovato A. PASTA 2.0: an improved server for protein aggregation prediction. Nucleic Acids Res. 2014. V. 42. P. W301-307.

23. Oliveberg M. Waltz, an exciting new move in amyloid prediction. Nat. Methods. 2010. V. 7. P. 187-188.

24. Conchillo-Solé O., de Groot N.S., Avilés F.X., Vendrell J., Daura X., Ventura S. AGGRESCAN: a server for the prediction and evaluation of "hot spots" of aggregation in polypeptides. BMC Bioinformatics. 2007. V. 8. P. 65.

25. R Core Team. R: A Language and Environment for Statistical Computing. Vienna: R Foundation for Statistical Computing, 2013.

26. Sievers F., Wilm A., Dineen D., Gibson T.J., Karplus K., Li W., et al. Fast, scalable generation of high-quality protein multiple sequence alignments using Clustal Omega. Mol. Syst. Biol. 2011. V. 7. P. 539.

27. Schneider T.D., Stephens R.M. Sequence logos: a new way to display consensus sequences. Nucleic Acids Res. 1990. V. 18. P. 6097-6100.

28. Crooks G.E., Hon G., Chandonia J.-M., Brenner S.E. WebLogo: a sequence logo generator. Genome Res. 2004. V. 14. P. 1188 1190 . 
29. Krieger E., Koraimann G., Vriend G. Increasing the precision of comparative models with YASARA NOVA-a self-parameterizing force field. Proteins: Struct. Funct. Bioinf. 2002. V. 47. P. 393-402.

30. Stec B. Plant thionins - the structural perspective. Cell. Mol. Life Sci. 2006. V. 63. P. 1370-1385.

31. Järvå M., Lay F.T., Hulett M.D., Kvansakul M. Structure of the defensin NsD7 in complex with PIP reveals that defensin: lipid oligomer topologies are dependent on lipid type. FEBS Lett. 2017. V. 591. P. 2482-2490.

32. Kvansakul M., Lay F.T., Adda C.G., Veneer P.K., Baxter A.A., Phan T.K., et al. Binding of phosphatidic acid by NsD7 mediates the formation of helical defensin-lipid oligomeric assemblies and membrane permeabilization. Proc. Natl. Acad. Sci. U.S.A. 2016. V. 113. P. 11202-11207.

33. Järvå M., Lay F.T., Phan T.K., Humble C., Poon I.K.H., Bleackley M.R., et al. X-ray structure of a carpet-like antimicrobial defensinphospholipid membrane disruption complex. Nat. Commun. 2018. V. 9. P. 1962. 